\title{
Short Communication: Genetic diversity of scalloped hammerhead sharks (Sphyrna lewini) landed in Muncar Fishing Port, Banyuwangi
}

\author{
FAQIH AKBAR ALGHOZALI", DIAH PERMATA WIJAYANTI, AGUS SABDONO \\ Department of Marine Science, Faculty of Fishery and Marine Science, Universitas Diponegoro. Jl. Prof. H. Soedarto, S.H., Tembalang, Semarang, \\ 50275, Central Java, Indonesia. Tel./fax.: +62-24-7474698, `email: faqihbig@ hotmail.com \\ Manuscript received: 6 February 2019. Revision accepted: 27 March 2019.
}

\begin{abstract}
Alghozali FA, Wijayanti DP, Sabdono A. 2019. Short Communication: Genetic diversity of scalloped hammerhead sharks (Sphyrna lewini) landed in Muncar Fishing Port, Banyuwangi. Biodiversitas 20: 1154-1159. The majority of sharks caught in Indonesian fisheries were bycatch products from the tuna longline fisheries, but some regions in Indonesia fish the sharks as their main target. One of these regions is located in Muncar, Banyuwangi, which fishes the endangered Scalloped Hammerhead sharks (Sphyrna lewini) as target species. This research aimed to study the genetic diversity of the endangered Scalloped Hammerhead sharks landed in Muncar Fishing Port, Banyuwangi. Genetic analysis was done through PCR (Polymerase Chain Reaction) amplification and sequencing of the mitochondrial DNA COI (Cytochrome Oxidase subunit I) gene. Out of the 37 samples collected, 30 were successfully amplified and sequenced.The results showed moderate haplotype diversity (Hd: $0,582 \pm 0,079)$ and low nucleotide diversity $(\pi: 0,00392 \pm 0,0024)$ with five haplotypes (h) and 26 polymorphic sites (S). Tajima's D neutrality model values indicated a population expansion event. Two different clades were determined through phylogenetic analysis and by GenBank sequences comparison. These results provided basic information and present status of the Scalloped Hammerhead sharks population genetically within the fishing ground (Makassar StraitKangean Islands).
\end{abstract}

Keywords: Genetic diversity, COI, scalloped hammerhead shark, Sphyrna lewini, Banyuwangi

\section{INTRODUCTION}

The Scalloped Hammerhead shark (Sphyrna lewini) is one of the three existing species of hammerhead sharks in Indonesia (White et al. 2006). The scalloped hammerhead is easily distinguished from other hammerhead shark species for having a distinctive indentation in the center of their head's front margin (Sadili et al. 2015). This species is circumglobal and widely distributed through all tropical and temperate waters all over the world. Although widely distributed, a genetic study revealed multiple subpopulations of this species (Duncan et al. 2006). The scalloped hammerhead shark can be found throughout the Indonesian waters and is the most abundant compared to the other hammerhead shark species (Harlyan et al. 2015). Adult scalloped hammerhead sharks can be found from the surface to a depth of $275 \mathrm{~m}$ of the continental and insular shelves (White et al. 2006).

There was an indication that the pups were abundant in their nursery ground and commonly found near the coastal area (Clarke 1971; Bejarano-Alvarez et al. 2010). This nursery ground at different times also serves as mating and pupping ground for adult sharks (Hazin et al. 2001). An adult female can produce between 14-41 pups in one reproduction cycle (Stevens and Lyle 1989; Hazin et al. 2001; Duncan et al. 2006; Bejarano-Alvarez et al. 2010). Adult males usually mature after reaching a length of 165 $175 \mathrm{~cm}$, and adult females mature at a longer length of 220$230 \mathrm{~cm}$. While they mature at different body lengths, both can reach a maximum length of $420 \mathrm{~cm}$ (White et al. 2006).

Like any other large shark species, the scalloped hammerhead shark fins are highly valued in the shark fins market. In the world's largest shark fin trading center in Hong Kong, their fins represent $4-5 \%$ of all the fins auctioned (Clarke et al. 2006). Genetic research in Indonesia claimed that the scalloped hammerhead shark fins are the second most traded fins in the traditional markets and shark-fin exporters (Sembiring et al. 2015). The large numbers of the scalloped hammerhead shark fins in the market were due to their habit to aggregate in large schools, which make them vulnerable to be caught as target and bycatch from trawls, purse seines, gillnets, longlines and inshore artisanal fisheries (Baum et al. 2007). The scalloped hammerhead shark had been listed as Vulnerable in the IUCN (International Union for Conservation of Nature) and the CITES (Convention on International Trade in Endangered Species) Appendix II (Baum et al. 2007). The Ministry of Maritime Affairs and Fisheries of Indonesia had banned the exports of all product forms derived from all hammerhead sharks species. The scalloped hammerhead is one of the most highly exploited shark species in Indonesia and is highly pressured by the capture fisheries industries, either as bycatch or target species (Fahmi and Dharmadi 2013; Gautama et al. 2018).

Muncar Fishing Port is located in Banyuwangi, East Java, and is one of the many fishing ports in Indonesia with the highest shark landing (Simeon et al. 2015). One of the most common shark species landed in Muncar Fishing Port 
is the scalloped hammerhead shark, Sphyrna lewini (Harlyan et al. 2015). Sharks late maturity, long gestation period and slow growth rate, combined with the high pressure from the capture fisheries industries may result in the decrease of their population (Dulvy et al. 2014). Low population size will then results in low genetic diversity (Bazin et al. 2006). This will render the species within a particular population to be vulnerable to diseases, parasites, predators and environmental changes (Amos and Hardwood 1998; Reed and Frankham 2003). Genetic studies provide important information, therefore it is used as tools to help solve problems in species management and conservation (Engelhardt et al. 2014; Larson et al. 2017). One of many benefits from genetic information is that scientists, NGOs, and governments will be able to tell how threatened and endangered the species is in the wild, and how urgent it is to take action towards the species' conservation. This research aims to study the genetic diversity of the endangered scalloped hammerhead sharks (S. lewini) landed in Muncar Fishing Port, Banyuwangi.

\section{MATERIALS AND METHODS}

\section{Study site}

The study site was located in Muncar Fishing Port, Banyuwangi District, East Java Province, Indonesia. The exact location was the Muncar Fishing Port situated on the eastern side of the province (Figure 1).

\section{Sample collection}

Muscle tissue samples of 37 sharks were collected from Muncar Fishing Port, Banyuwangi. Shark species was visually identified following White et al. (2006) before sampling to avoid misidentification (Figure 2). Samples were taken using a knife and tweezers which had been sterilized with $96 \%$ ethanol and rinsed with sterilized sea water to prevent contamination. Samples were then preserved in vial tubes containing $96 \%$ ethanol and stored at room temperature (Abercrombie et al. 2005). Fishing ground coordinates and locations were collected through interview with the fishermen to assume the origin of the samples. Only one fisherman was interviewed due to the shared fishing ground locations of all the shark fishing vessels in Muncar, and they are all under the same fisheries management.

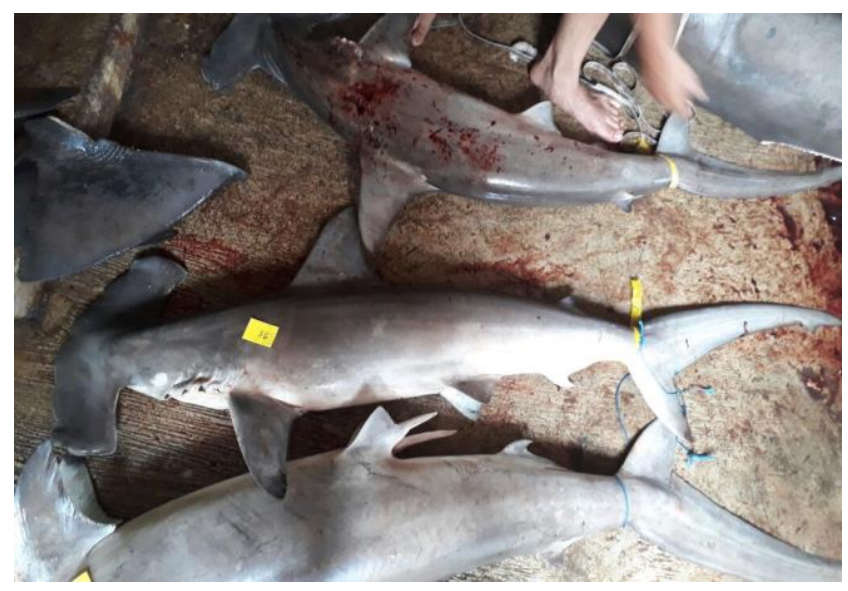

Figure 2: Sphyrna lewini landed in Muncar Fishing Port, Banyuwangi, East Java, Indonesia

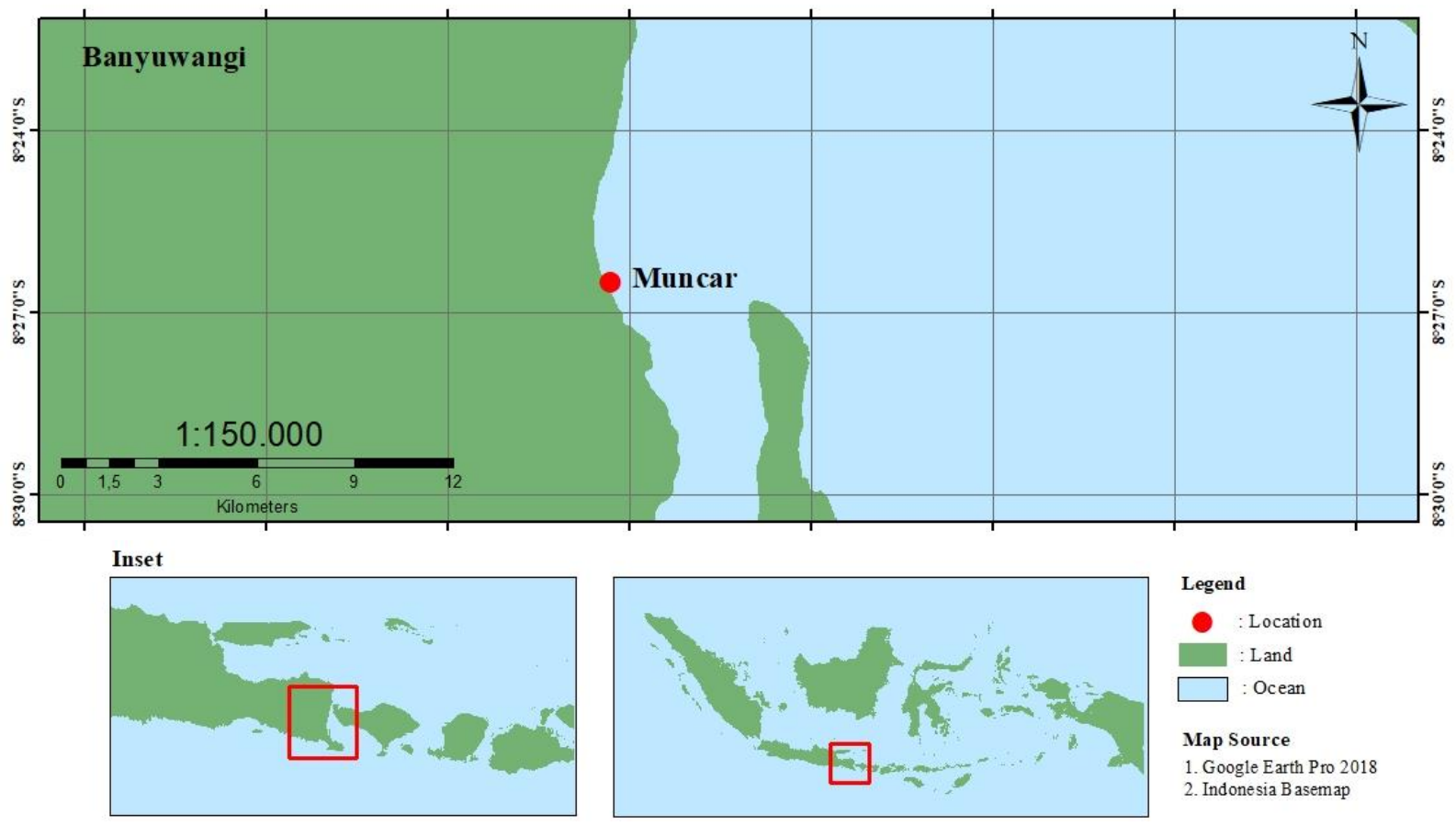

Figure 1: Location of study and sampling site in Muncar Fishing Port, Banyuwangi, East Java, Indonesia (8²6’30.73”S, $\left.114^{\circ} 20^{\prime} 41.24^{\prime \prime} \mathrm{E}\right)$ 


\section{DNA extraction, PCR amplification, and DNA barcoding}

Genomic DNA was extracted from samples using a modified Chelex 100 method (Walsh et al. 1991; GalalKhallaf et al. 2014). Approximately $1 \mathrm{mg}$ muscle tissue sample was placed in an Eppendorf tube containing $500 \mu \mathrm{L}$ $10 \%$ Chelex solution combined with $7 \mu \mathrm{L}$ proteinase K (10 $\mathrm{mg} / \mathrm{mL}$ ). Samples were then incubated in a heating block at $55^{\circ} \mathrm{C}$ for 90 minutes to release DNA, followed by $100{ }^{\circ} \mathrm{C}$ for 20 minutes to deactivate the proteinase $\mathrm{K}$. Aliquots of DNA were moved into a new tube and stored at $4{ }^{\circ} \mathrm{C}$ for further analysis.

Mitochondrial DNA COI (Cytochrome Oxidase subunit I) partial gene fragments were amplified using PCR (Polymerase Chain Reaction) method. A $26 \mu \mathrm{L}$ reaction mixture containing $1 \mu \mathrm{L}$ of DNA template, $12.5 \mu \mathrm{L}$ of KAPA Taq PCR kit $\left(25 \mu \mathrm{M} \mathrm{MgCl}_{2}, 5 \mathrm{U} / \mu \mathrm{L}\right.$ Taq Polymerase, 10x Taq Buffer, and $10 \mu \mathrm{M}$ dNTPs), $1.25 \mu \mathrm{L}$ $10 \mathrm{mM}$ of forward primer, $1.25 \mu \mathrm{L} 10 \mathrm{mM}$ of reverse primer and $10 \mu \mathrm{L}$ of distilled water. The primers used were Fish BCL: 5'-TCA ACY AAT CAY AAA GAT ATY GGC AC-3' (forward) and Fish BCH: 5'-ACT TCY GGG TGR CCR AAR AAT CA-3' (reverse) (Baldwin et al. 2009). The mixture was run in a thermal cycler using the following PCR cycle: $95^{\circ} \mathrm{C}$ initial denaturation for 5 minutes; followed by 38 cycles of denaturation at $94{ }^{\circ} \mathrm{C}$ for 30 seconds, primer annealing at $48{ }^{\circ} \mathrm{C}$ for 30 seconds and extension at $72{ }^{\circ} \mathrm{C}$ for 45 seconds; and a final extension step at $72{ }^{\circ} \mathrm{C}$ for 5 minutes. PCR products from the samples were then visualized for DNA band via electrophoresis on a $1 \%$ agarose gel and $\mathrm{EtBr}$ (ethidium bromide) staining (Sembiring et al. 2015). PCR products were then sent to Genetika Science Indonesia to be purified and sequenced.

Table 1. Sphyrna lewini DNA sequences and sequences from NCBI GenBank

\begin{tabular}{llc}
\hline Location & Species & $\begin{array}{c}\text { Accession } \\
\text { Code }\end{array}$ \\
\hline Hawaii & $\begin{array}{l}\text { Sphyrna lewini } \\
\text { Papua New Guinea }\end{array}$ & MG816735 \\
California & Sphyrna lewini & MF508692 \\
Philippine & Sphyrna lewini & GU440527 \\
Australia & Sphyrna lewini & KU366669 \\
Indonesia & Sphyrna lewini & KF793757 \\
Indonesia 2 & Sphyrna lewini & KF793742 \\
Madagascar & Sphyrna lewini & HQ171776 \\
Myanmar & Sphyrna lewini & MH235723 \\
Saudi Arabia & Sphyrna lewini & KM396950 \\
Brazil & Sphyrna lewini & JQ365585 \\
Mexico & Sphyrna lewini & MG838000 \\
H1 Sample & Sphyrna lewini & LC422406 \\
(S: 1, 5, 7, 17, 19, 27, 29, 30) & & \\
H2 Sample & Sphyrna lewini & LC422407 \\
(S: 2-4, 9-12, 14-16, 18, 21- & & \\
23, 25-26, 28, 31) & & \\
H3 Sample (S: 6, 8) & Sphyrna lewini & LC422408 \\
H4 Sample (S20) & Sphyrna lewini & LC422409 \\
H5 Sample (S24) & Sphyrna lewini & LC422410 \\
\hline
\end{tabular}

\section{Data analysis}

Forward and reverse sequences of each sample was checked, aligned and edited using MEGA 5.2 (Tamura et al. 2007). Species identification from the sequences was made before data analyses using BLAST (Basic Local Alignment Search Tool) by matching them with the sequences from NCBI (National Center for Biotechnology Information) GenBank. Phylogenetic tree from the sequences was made using the Maximum Likelihood method, Kimura-2-parameter model and 1000 bootstrap replicate. Several sequences from NCBI GenBank were included in the phylogenetic tree for comparison (Table 1). Genetic distances between each sequence were analyzed using Pairwise Distance method and Kimura-2-parameter (Kimura 1980; Tamura et al. 2011). Genetic diversity was examined by determining the numbers of segregating sites (S), haplotypes number (h), haplotype diversity (Hd) and nucleotide diversity $(\pi)$. Tajima's D and Fu's FS were calculated for neutrality test (Librado and Rozas 2009). Fishing ground coordinates were processed and made into a fishing ground map using ArcMap 10.3.

\section{RESULTS AND DISCUSSION}

\section{DNA extraction, PCR amplification, and DNA barcoding}

A total of 30 out of 37 samples were successfully amplified and sequenced. The final edited sequences had length of 574 bp. All sequences were identified as Sphyrna lewini with Identify values of $99-100 \%$ and were submitted to the DDBJ (DNA Data Bank of Japan) under the accession number of LC422406-LC422410 (Table 2).

\section{Phylogenetic tree}

Two clades were determined from the constructed phylogenetic tree. Clade 1 consisted of all but one sample, S24 Fish BCL which forms clade 2 (Figure 3). The S24 Fish BCL sample also had the highest genetic distance values against other samples with 0.041 and 0.043 respectively.

\section{Genetic diversity and neutrality test}

Data analysis results showed five different haplotype (h) and 26 polymorphic sites (S) (Table 3 ). Haplotype (Hd) and nucleotide diversity $(\pi)$ of all 30 samples were $0.582 \pm$ 0.079 and $0.00392 \pm 0.0024$ respectively. Tajima's D neutrality test resulted in a significant negative value of $2.346(\mathrm{P}<0.05)$ while Fu's FS neutrality test resulted in a not significant positive value of 1.721 ( $\mathrm{P}>0.05)$ (Table 4).

\section{Discussion}

The results of BLAST analysis showed that all samples were identified as Sphyrna lewini with Identify values of 99-100\%. Two clades were determined by looking at the bootstrap values and the genetic distances between samples. S24 Fish BCL sample which forms clade 2 exhibit a strong branch position in the phylogenetic tree with a bootstrap value of $100 \%$. Hillis and Bull (1993) and Nei 
and Kumar (2000) mentioned that a bootstrap value higher than $95 \%$ is considered good and provide strong support in a phylogenetic tree. Felsenstein (1985) claimed that bootstrap value is only seen as repeatability and not as an accuracy. Therefore, while clade 2 exhibits strong support in the tree, clade 1 cannot be considered inaccurate. At the same time, the low genetic distances between samples indicate that clade 1 and 2 are closely related (Nei 1972).

The phylogenetic tree showed that Sphyrna lewini from clade 2 shares genetic relations with $S$. lewini from Madagascar, Myanmar, and Saudi Arabia, while S. lewini from clade 1 share genetic relations with $S$. lewini from Hawaii, Papua New Guinea, California, Philippine and Australia. The high number of pups (14-41) per litter produced by a scalloped hammerhead shark per reproduction cycle and the high connectivity of coastal nursery grounds can possibly be the reason as to why genetics from different clades can be found in Indonesia (Bejarano-Alvarez et al. 2010; Duncan et al. 2006; Hazin et al. 2001; Stevens and Lyle 1989). The scalloped hammerhead sharks ability to cover a distance of about 627 $\mathrm{km}$ might also be the reason they can be found in countries with tropical climate (Baum et al. 2007; Bessudo et al. 2011a, b).

Genetic diversity values exhibit moderate haplotype and low nucleotide diversity (Hobbs et al., 2013; Nei, 1987). Generally, migrational species will have high genetic diversity, but either natural or fisheries based high mortality rate in Sphyrna lewini can decrease their genetic diversity (Bessudo et al. 2011b; Fetzner Jr and Crandall 2001). Tajima's D neutrality test indicates a population expansion event. This also leads to the possibilities of a population bottleneck event before the population expansion, which was characterized by the appearance of more abundant haplotypes with fewer samples (Schmidt and Pool 2002). However, further researches are needed to verify this hypothesis. The $S$. lewini populations in Indonesia is threatened due to the high exploitation rate and fisheries pressure (Gautama et al. 2018). The capture of immature adults and juvenile can also lead to the reduction of their population size from the decrease in population recruitment (Diekert and Rouyer 2011). This will eventually lower the genetic diversity of $S$. lewini in Indonesia (Fetzner and Crandall 2001).

Table 2. BLAST Results

\begin{tabular}{llcc}
\hline Sample code & $\begin{array}{c}\text { BLAST } \\
\text { Result }\end{array}$ & $\begin{array}{c}\text { Identify } \\
(\%)\end{array}$ & $\begin{array}{c}\text { Accession } \\
\text { Code }\end{array}$ \\
\hline S1 Fish BCL & Sphyrna lewini & 100 & MF508691 \\
S2 Fish BCL & Sphyrna lewini & 100 & MF508688 \\
S3 Fish BCL & Sphyrna lewini & 100 & MF508688 \\
S4 Fish BCL & Sphyrna lewini & 100 & MF508688 \\
S5 Fish BCL & Sphyrna lewini & 100 & MF508691 \\
S6 Fish BCL & Sphyrna lewini & 100 & MF508690 \\
S7 Fish BCL & Sphyrna lewini & 100 & MF508691 \\
S8 Fish BCL & Sphyrna lewini & 100 & MF508690 \\
S9 Fish BCL & Sphyrna lewini & 100 & MF508688 \\
S10 Fish BCL & Sphyrna lewini & 100 & MF508688 \\
S11 Fish BCL & Sphyrna lewini & 100 & MF508688 \\
S12 Fish BCL & Sphyrna lewini & 100 & MF508688 \\
S14 Fish BCL & Sphyrna lewini & 100 & MF508688 \\
S15 Fish BCL & Sphyrna lewini & 100 & MF508688 \\
S16 Fish BCL & Sphyrna lewini & 100 & MF508688 \\
S17 Fish BCL & Sphyrna lewini & 100 & MF508691 \\
S18 Fish BCL & Sphyrna lewini & 100 & MF508688 \\
S19 Fish BCL & Sphyrna lewini & 100 & MF508691 \\
S20 Fish BCL & Sphyrna lewini & 99 & MF508688 \\
S21 Fish BCL & Sphyrna lewini & 100 & MF508688 \\
S22 Fish BCL & Sphyrna lewini & 100 & MF508688 \\
S23 Fish BCL & Sphyrna lewini & 100 & MF508688 \\
S24 Fish BCL & Sphyrna lewini & 100 & KP177306 \\
S25 Fish BCL & Sphyrna lewini & 100 & MF508688 \\
S26 Fish BCL & Sphyrna lewini & 100 & MF508688 \\
S27 Fish BCL & Sphyrna lewini & 100 & MF508688 \\
S28 Fish BCH & Sphyrna lewini & 100 & MF508691 \\
S29 Fish BCL & Sphyrna lewini & 100 & MF508688 \\
S30 Fish BCL & Sphyrna lewini & 100 & MF508691 \\
S31 Fish BCL & Sphyrna lewini & 100 & MF508691 \\
\hline & & & \\
& &
\end{tabular}

Table 4. Genetic diversity indices and neutrality test values

\begin{tabular}{ccccccc}
\hline $\mathbf{n}$ & $\mathbf{S}$ & $\mathbf{h}$ & $\mathbf{H d} \pm \mathbf{S d}$ & $\boldsymbol{\pi} \pm \mathbf{S d}$ & $\mathbf{D}^{*}$ & $\mathbf{F S} * *$ \\
\hline 30 & 26 & 5 & $0.582 \pm 0.079$ & $0.00392 \pm 0.0024$ & -2.346 & 1.721 \\
\hline Note: & $* \mathrm{P}<0.05, * * \mathrm{P}>0.05$ &
\end{tabular}

Table 3. Haplotype and number of polymorphic sites

\begin{tabular}{|c|c|c|c|c|c|c|c|c|c|c|c|c|c|c|c|c|c|c|c|c|c|c|c|c|c|c|}
\hline \multirow{4}{*}{ Haplotype } & \multicolumn{26}{|c|}{ Polymorphic Sites } \\
\hline & & & & 1 & 1 & 1 & 1 & 1 & 1 & 2 & 2 & 2 & 3 & 3 & 3 & 3 & 3 & 3 & 4 & 4 & 4 & 4 & 4 & 5 & 5 & 5 \\
\hline & & 3 & 7 & 1 & 4 & 5 & 7 & 8 & 9 & 0 & 3 & 8 & 1 & 1 & 3 & 4 & 5 & 7 & 0 & 1 & 2 & 6 & 9 & 0 & 4 & 5 \\
\hline & 7 & 6 & 8 & 4 & 7 & $\mathbf{0}$ & 4 & 3 & 5 & 7 & 8 & 8 & 2 & 5 & 4 & 8 & 1 & 5 & 5 & 1 & 9 & 5 & 2 & 7 & $\mathbf{0}$ & 2 \\
\hline $\mathrm{H} 1$ & $\mathrm{C}$ & A & $\mathrm{T}$ & $\mathrm{G}$ & A & $\mathrm{T}$ & $\mathrm{C}$ & $\mathrm{T}$ & $\mathrm{T}$ & $\mathrm{C}$ & $\mathrm{C}$ & $\mathrm{T}$ & $\mathrm{C}$ & $\mathrm{C}$ & $\mathrm{T}$ & $\mathrm{T}$ & $\mathrm{C}$ & $\mathrm{T}$ & $\mathrm{C}$ & $\mathrm{C}$ & $\mathrm{T}$ & $\mathrm{C}$ & A & $\mathrm{T}$ & $\mathrm{C}$ & $\mathrm{C}$ \\
\hline $\mathrm{H} 2$ & . & . & . & . & . & . & . & . & . & . & . & . & . & & . & . & . & . & . & . & . & . & . & . & . & $\mathrm{T}$ \\
\hline H3 & . & 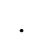 & $\mathrm{C}$ & . & . & . & . & . & . & . & . & 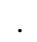 & . & $\mathrm{T}$ & . & . & . & . & . & . & . & . & . & . & . & $\mathrm{T}$ \\
\hline H4 & $\cdot$ & & . & . & . & . & . & . & . & . & . & 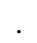 & . & 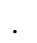 & . & . & . & . & . & $\mathrm{T}$ & . & 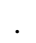 & . & . & . & $\mathrm{T}$ \\
\hline H5 & $\mathrm{T}$ & $\mathrm{C}$ & . & A & $\mathrm{C}$ & $\mathrm{G}$ & $\mathrm{T}$ & $\mathrm{C}$ & $\mathrm{C}$ & $\mathrm{T}$ & $\mathrm{T}$ & $\mathrm{C}$ & $\mathrm{T}$ & $\mathrm{T}$ & $\mathrm{C}$ & $\mathrm{C}$ & A & $\mathrm{C}$ & $\mathrm{T}$ & . & $\mathrm{C}$ & $\mathrm{T}$ & C & $\mathrm{C}$ & $\mathrm{T}$ & $\mathrm{T}$ \\
\hline
\end{tabular}




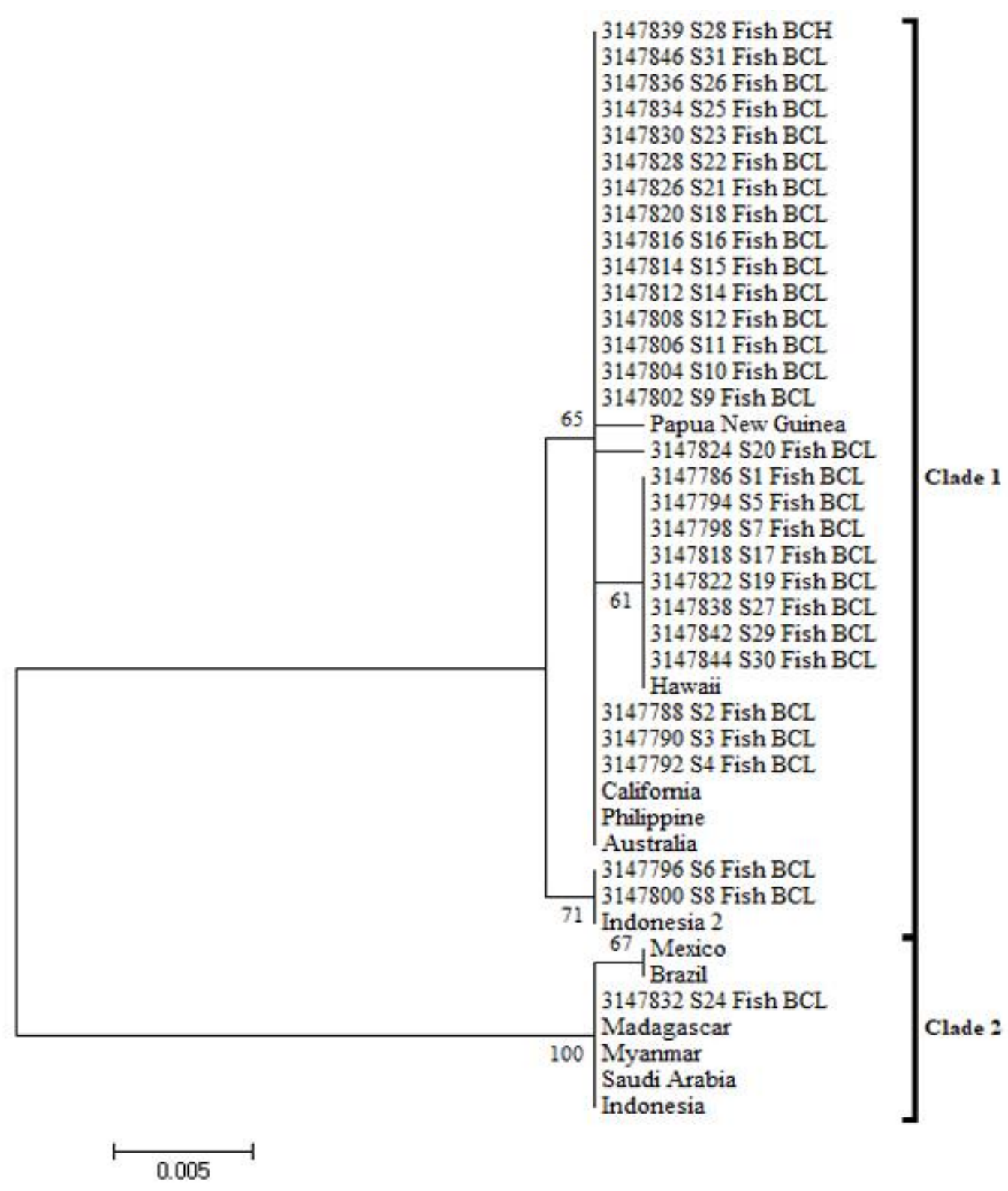

Figure 3. Phylogenetic tree of Sphyrna lewini landed in Muncar Fishing Port, Banyuwangi, East Java, Indonesia

The genetic diversity of Sphyrna lewini landed in Muncar can be considered low moderate from the analyzed indices. The possibility of a bottleneck event before the population expansion of Sphyrna lewini from the fishing grounds (Makassar Strait-Kangean Island) can no longer be ignored. Further researches with a larger area of sampling to obtain more robust data may provide more information on the genetic diversity of Sphyrna lewini. Therefore, the genetic diversity of this species could be fully understood, as well as the species population condition in Indonesia. Temporal and spatial researches of their migration, mating and pupping season are also crucial to implement effective actions in the field of this species conservation.

\section{ACKNOWLEDGEMENTS}

We would like to thanks C.P. Nindityawan, E.R. Davinto, D.I. Bagus, D. Dirgantara, S. Muchlisin, N. Kholilah, M.D. Almalik, T.E. Putri, C.D. Ruswanti, F.L. H. Nasution, M. Bachtiar, D.P. Hernowo, S. Nabila and R. Fitriani for their support and help on the success of this study. The study was partly funded by Diponegoro University, Semarang, Indonesia through RPI project of DPW under Decree No. SP DIPA-042.01.2.400898/2016, December $7^{\text {th }}, 2015$ the fiscal year 2016 . 


\section{REFERENCES}

Abercrombie DL, Clarke SC, Shivji MS. 2005. Global-scale genetic identification of hammerhead sharks: application to assessment of the international fin trade and law enforcement. Conserv Genet 6: 775788.

Alvi M. 2016. A Manual for Selecting Sampling Techniques in Research University of Karachi. Munich Personal RePEc Archive, Munich.

Amos W. Hardwood J. 1998. Factors affecting levels of genetic diversity in natural populations. Phil Trans R Soc London B 353: 177-186.

Baldwin CC, Mounts JH, Smith DG, Weigt LA. 2009. Genetic identification and color descriptions of early life-history stages of Belizean Phaeoptyx and Astrapogon (Teleostei: Apogonidae) with comments on identification of adult Phaeoptyx. Zootaxa 2008: 1-22.

Baum J, Clarke S, Domingo A, Ducrocq M, Lamonaca AF, Gaibor N, Graham R, Jorgensen S, Kotas JE, Medina E, Martinez-Ortiz J, Monzini TSJ, Morales MR, Navarro SS, Perez-Jimenez JC, Ruiz C Smith W, Valenti SV, Vooren CM. 2007. Sphyrna lewini. The IUCN Red List of Threatened Species 2007: e.T39385A10190088.

Bazin E, Glemin S, Galtier N. 2006. Population size does not influence mitochondrial genetic diversity in animals. Science 312: 570-572.

Bejarano-Alvarez M, Galvan-Magana F, Ochoa-Baez RI. 2010 Reproductive biology of the scalloped hammerhead shark Sphyrna lewini (Chondrichthyes: Sphyrnidae) off South-West Mexico. Aqua 17 (1): 11-22.

Bessudo S, Soler GA, Klimley AP, Ketchum JT, Hearn A, Arauz R, Guzman A, Calmettes B. 2011b. Vertical and horizontal movement of the scalloped hammerhead shark (Sphyrna lewini) around Malpelo and Cocos Islands (Tropical Eastern Pacific) using satellite telemetry. Bol Invest Mar Cost 40: 91-106.

Bessudo S, Soler GA, Klimley AP, Ketchum JT, Hearn A, Arauz R. 2011a. Residency of the Scalloped Hammerhead Shark (Sphyrna lewini) at Malpelo Island and evidence of migration to other islands in the eastern tropical Pacific. Environ Biol Fish 91: 165-176.

Clarke SC, Magnussen JE, Abercrombie DL, McCallister MK, Shivji MS. 2006. Identification of shark species composition and proportion in the hong kong shark fin market based on molecular genetics and trade records. Conserv Biol 20 (1): 201-211.

Clarke TA. 1971. The ecology of the scalloped hammerhead shark, Sphyrna lewini, in Hawaii. Pacific Sci 25: 133-144.

Diekert F, Rouyer T. 2011. Managing Growth-Overfishing is More Important than Managing Recruitment-Overfishing. The University of Oslo, Norway.

Dulvy NK, Fowler SL, Musick JA, Cavanagh RD, Kyne PM, Harrison LR, Carlson JK, Davidson LNK, Fordham SV, Francis MP, Pollock CM, Simpfendorfer CA, Burgess GH, Carpenter KE, Compagno LJV, Ebert DA, Gibson C, Heupel MR, Livingstone SR, Sanciangco JC, Stevens JD, Valenti S, White WT. 2014. Extinction risk and conservation of the worlds sharks and rays. eLife 3:e00590.

Duncan KM, Martin AP, Bowen BW, DE Couet HG. 2006. Global phylogeography of the scalloped hammerhead shark (Sphyrna lewini). Mol Ecol 15 (8): 2239-2251.

Engelhardt KAM, Lloyd MW, Neel MC. 2014. Effects of genetic diversity on conservation and restoration potential at individual, population, and regional scales. Biol Conserv 179: 6-16.

Fahmi, Dharmadi. 2013. Tinjauan Status Perikanan Hiu dan Upaya Konservasinya di Indonesia. Direktorat Konservasi Kawasan dan Jenis Ikan, Kementerian Kelautan dan Perikanan, Jakarta [Indonesian]

Felsenstein J. 1985. Confidence limits on phylogenies: an approach using the bootstrap. Evolution 39 (4): 783-791.

Fetzner Jr JW, Crandall KA. 2001. Genetic variation. In: Holdich DM (ed.). Biology of Freshwater Crayfish. Blackwell Science, Oxford, UK.

Galal-Khallaf A, Ardura A, Mohammed-Geba K, Borell YJ, GarciaVasquez E. 2014. DNA barcoding reveals a high level of mislabeling in Egyptian fish fillets. Food Control 46: 441-445.
Gautama DA, Prima P, Andhika, Yuneni RR, Yudiarso P. 2018. Life history and exploitation rate of juvenile scalloped hammerhead (Sphyrna lewini) in the Indonesian waters. Simposium Hiu dan Pari di Indonesia ke-2. Jakarta.

Harlyan LI, Kusumasari A, Anugrah M, Yuneni RR. 2015. Pendataan Hiu yang Didaratkan di Pelabuhan Perikanan Pantai Muncar, Banyuwangi. Prosiding Simposium Hiu dan Pari di Indonesia, Kementerian Kelautan dan Perikanan. Jakarta. [Indonesian]

Hazin F, Fischer A, Broadhurst M. 2001. Aspects of reproductive biology of the scalloped hammerhead shark, Sphyrna lewini, off Northeastern Brazil. Environ Biol Fish 61: 151-159.

Hillis DM, Bull JJ. 1993. An empirical test of bootstrapping as a method for assessing confidence in phylogenetic analysis. Syst Biol 42 (2): 182-192.

Hobbs JPA, van Herwerden L, Jerry DR, Jones GP, Munday PL. 2013. High genetic diversity in geographically remote populations of endemic and widespread coral reef angelfishes (Genus: Centropyge). Diversity 5: 39-50.

Kimura M. 1980. A simple method for estimating evolutionary rates of base substitutions through comparative studies of nucleotide sequences. J Mol Evol 16 (2): 111-120.

Larson SE, Daly-Engel TS, Phillips NM. 2017. Review of current conservation genetic analyses of northeast Pacific sharks. Adv Mar Biol 17: 79-110.

Librado P, Rozas J. 2009. DnaSP v5: A software for comprehensive analysis of DNA polymorphism data. Bioinformatics. 25: 1451-1452.

Nei M, Kumar S. 2000. Molecular Evolution and Phylogenetics. Oxford University Press, New York.

Nei M. 1972. Genetic distance between populations. Amer Nat 106 (949): 283-292.

Nei M. 1987. Molecular Genetics. Columbia University New York Press, New York.

Reed DH, Frarnkham R. 2003. Correlation between fitness and genetic diversity. Conserv Biol 17 (1): 230-237.

Sadili D, Fahmi, Dharmadi, Sarmintohadi, Ramli I. 2015. Pedoman Identifikasi dan Pendataan Hiu Apendiks II CITES. Direktorat Konservasi Kawasan dan Jenis Ikan, Kementerian Kelautan dan Perikanan. Jakarta. [Indonesian]

Schmidt D, Pool J. 2002. The Effect of Population History on the Distribution of the Tajima's D Statistic. University of Nevada, USA.

Sembiring A, Pertiwi NPD, Mahardini A, Wulandari R, Kurniasih EM, Kuncoro AW, Cahyani NKD, Anggoro AW, Ulfa M, Madduppa H, Carpenter KE, Barber PH, Mahardika GN. 2015. DNA barcoding reveals targeted fisheries for endangered sharks in Indonesia. Fisher Res 164: 130-134.

Simeon BM, Apriliani IM, Gautama DA. 2015. Strategi Pengalihan Operasi Penangkapan Hiu di Pelabuhan Perikanan Pantai Muncar, Kabupaten Banyuwangi, Jawa Timur. Prosiding Simposium Hiu dan Pari di Indonesia, Kementerian Kelautan dan Perikanan. Jakarta. [Indonesian]

Stevens JD, Lyle JM. 1989. Biology of Three Hammerhead Sharks (Eusphyra blochii, Sphyrna mokarran and S. lewini) from Northern Australia. Aust J Mar Freshwater Res 40: 129-146.

Stevens JD. 1973. Stomach Contents of the Blue Shark (Prionace glaucal L.) off South-West England. J Mar Bio Ass UK 53: 357-361.

Tamura K, Dudley J, Nei M, Kumar S. 2007. MEGA4: Molecular Evolutionary Genetics Analysis (MEGA) Software Version 4.0. Mol Biol Evol 24: 1596-1599.

Tamura K, Peterson D, Peterson N, Stecher G, Nei M, Kumar S. 2011. Mega 5: Molecular Evolutionary Genetics Analysis Using Maximum Likelihood, Evolutionary Distance, and Maximum Parsimony Methods. Mol Biol Evol 24: 1596-1599.

Walsh PS, Metzger DA, Higuchi R. 1991. Chelex 100 as a medium for simple extraction of DNA for PCR-based typing from forensic material. Biotechniques 10 (4): 506-13.

White WT, Last PR, Stevens JD, Yearsley GK, Fahmi, Dharmadi. 2006. Economically Important Sharks and Rays of Indonesia. Australian Centre for International Agricultural Research, Canberra. 